\title{
Karaimi we Wrocławiu
}

\section{MARIOLA ABKOWICZ}

Narodowy Spis Powszechny z roku 2002 podaje liczbę 45 osób, które zadeklarowały narodowość karaimską. Według karaimskich rejestrów liczba ta wynosi około 120 osób. Duża dysproporcja pomiędzy tymi wartościami wynika z różnego samookreślenia przedstawicieli tej społeczności. Podstawowym kryterium jest: narodowość - Karaim, wyznanie - karaimskie. Pozostałe to: narodowość - Polak, wyznanie - karaimskie oraz narodowość - Polak, wyznanie inne niż karaimskie. Są też osoby, które z różnych przyczyn nie określają narodowości ani wyznania. W związku z powyższym nie jesteśmy w stanie stwierdzić, jaka jest faktyczna liczba osób pochodzenia karaimskiego w Polsce. Trudności sprawia szczególnie oszacowanie liczby osób o korzeniach karaimskich, lecz nie utrzymujących kontaktów ze środowiskami karaimskimi. Na podstawie posiadanych danych możemy jedynie w dużym przybliżeniu założyć, że może chodzić o od 500 do nawet 1000 osób. Do takich przypuszczeń asumpt dają badania przeprowadzone wśród społeczności karaimskiej w Polsce i na Litwie w roku 1997, których wyniki opublikowane zostały w roku 2003. Podczas badań terenowych prowadzonych na Dolnym Śląsku wśród rodzin karaimskich zebrano 78 ankiet od rodzin 15 Karaimów zamieszkujących na tych terenach.

Osadnictwo karaimskie na Dolnym Śląsku i Śląsku Opolskim rozpoczęło się w roku 1945, kiedy to dyrektorem cukrowni w Otmuchowie koło Nysy został mianowany Józef Firkowicz, Karaim trocki zamieszkujący przed wojną na Mazowszu. Karaimi przybywali do Wrocławia i Opola wraz z transportami repatriantów, po demobilizacji z Wojska Polskiego, w ramach łączenia rodzin i „za nauką”. We Wrocławiu osiedlali się głównie przybysze z Wilna i Trok (Litwa), a także Halicza (Ukraina). Większość członków społeczności karaimskiej z Łucka (Ukraina) znalazła swoje nowe siedlisko w Opolu - zgodnie z kierunkiem transportów repatriacyjnych. Pośród naukowców, którzy przybyli do Wrocławia z Warszawy by tworzyć wrocławskie uczelnie był filolog orientalny, karaimoznawca prof. Ananiasz Zajączkowski. Wraz z inauguracją pierwszego roku akademickiego na Politechnice Wrocławskiej studia rozpoczęli późniejsi profesorowie: Szymon Firkowicz, wybitny matematyk i Szymon Pilecki, fizyk (inżynieria materiałowa) - inicjator i twórca dyfuzyjnej teorii zmęczenia metali. W ich studenckim mieszkaniu, w dwóch i pół pokojach zamieszkała później 
Zofia Łopatto z synami. Dom wspomnianego wyżej Józefa Firkowicza był miejscem, które do którego ściągali na Dolny Śląsk spokrewnieni z nim Firkowicze, Abkowicze i Kobeccy. W roku 1946 rozpoczął działalność kapłańską przybyły z Wilna hazzan Rafał Abkowicz. W tymże samym roku społeczność karaimska odnotowała pierwszą stratę - w Przeworynie koło Strzelina wskutek utonięcia zmarł czteroletni Jerzyk, syn Michała Firkowicza, późniejszego pracownika NBP.

W roku 1947 przy okazji wyborów delegatów na zjazd organizowany przez Karaimski Tymczasowy Zarząd Duchowny spisano Karaimów dżymatu wrocławskiego karaimskiej gminy wyznaniowej. Na liście znalazły się nazwiska 57 osób. Byli to przedstawiciele rodzin z Litwy o nazwiskach: Abkowicz - 6, Dubiński - 6, Firkowicz - 7, Kobecki - 7, Nowicki - 2, Łopatto - 4, Pilecki - 3, Robaczewski - 2, Tynfowicz - 1; z Ukrainy - z Łucka: Boroński (Bezekowicz) 1, Eszwowicz - 1, Gołub - 2, Isakowicz - 1, Kaliski - 1, Nowicki - 7, Rojecki - 1, Rudkowski - 2; z Halicza: Abrahamowicz - 1, Szulimowicz - 1. Ogółem społeczność liczyła 38 mężczyzn i 19 kobiet z 15 rodzin.

Liczba ta w kolejnych latach zmniejszała się. Najczęstszymi przyczynami tego były migracje głównie do Trójmiasta i Warszawy, a także stopniowe wymieranie przy niskim odsetku małżeństw karaimskich i niskim przyroście naturalnym. Powodowało to stopniowe zmniejszanie się liczebności społeczności karaimskiej na Dolnym Śląsku i Śląsku Opolskim.

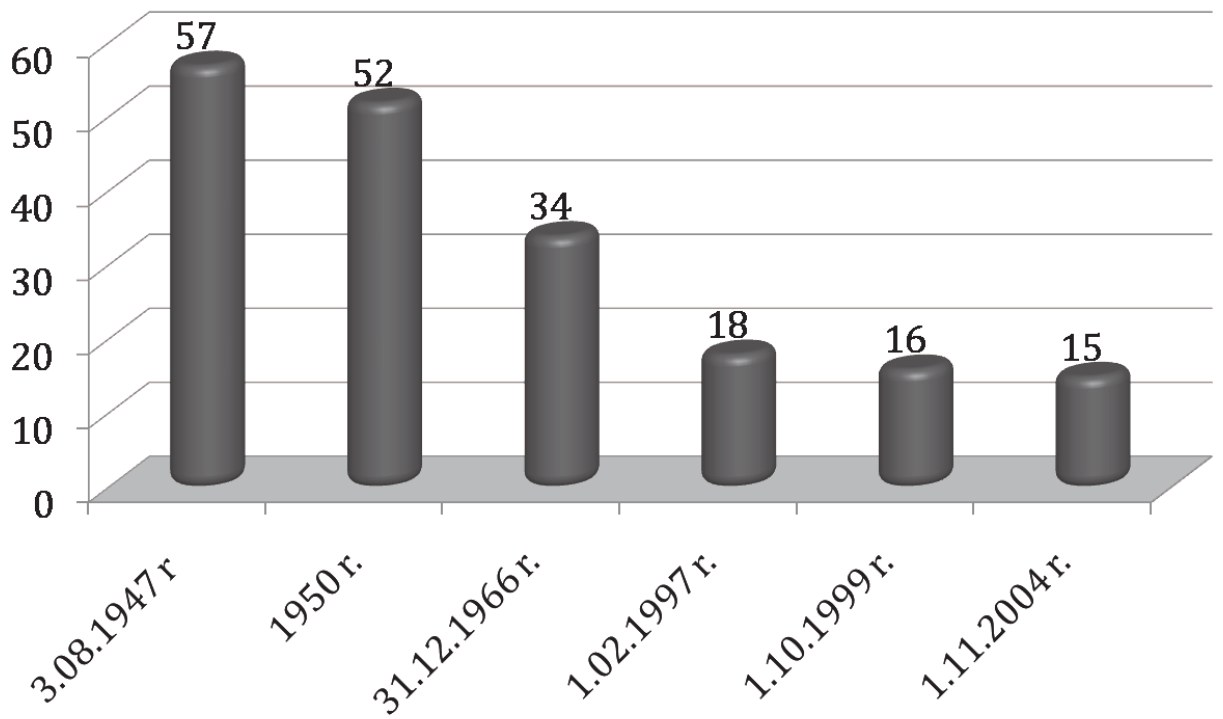

Liczebność społeczności karaimskiej na Dolnym Śląsku i Śląsku Opolskim w latach $1947-2004 r$. 
Działalność organizacyjna społeczności karaimskiej rozpoczęła się od próby odtworzenia struktur religijnych zgodnie z zapisami ustawy o stosunku Państwa do Karaimskiego Związku Religijnego w Rzeczypospolitej Polskiej z dnia 21 kwietnia 1936 r. (Dz. U. 1936. Nr 30 poz. 241). Nowoprzybyła społeczność podjęła próby reaktywowania działalności w nowych warunkach, organizując się w dżymaty. 11 listopada 1945 roku odbyło się w Podkowie Leśnej zebranie organizacyjne członków Karaimskiego Związku Religijnego w Polsce, na którym wybrano władze tymczasowe i określono potrzeby społeczne. Wzrost liczby Karaimów osiedlających się w Trójmieście, Wrocławiu i Opolu powodował konieczność powołania terenowych delegatur, których zadaniem była opieka nad repatriantami oraz inwentaryzacja i zabezpieczenie przywożonych przez nich przedmiotów kultu i materiałów dotyczących historii dawnych gmin. W dniach 21-22 grudnia 1946 r. zorganizowano we Wrocławiu Pierwszą Konferencję Młodzieży Karaimskiej, którą otworzyło nabożeństwo odprawione przez hazzana Rafała Abkowicza (1895-1992). W wystąpieniach podczas konferencji podejmowano problemy związane z utrzymaniem i kontynuowaniem tradycji i obyczajów, pogłębiania świadomości własnej tożsamości narodowej. Zdecydowano o utworzeniu w ramach KZR Sekcji Młodzieży Karaimskiej. Szerokie plany działalności zweryfikowały jednak kolejne lata. Początkowo, jeszcze w latach 40 . i 50. żywa była potrzeba aktywnego uczestniczenia w życiu społecznym i religijnym. W latach 1946 i 1947 we Wrocławiu zostały wydane dwa numery „Myśli Karaimskiej” (potem przekształconej w „Przegląd Orientalistyczny”). Spotkania religijne odbywały się początkowo w domach prywatnych. W roku 1952 pomieszczenia we wrocławskim mieszkaniu hazzana Rafała Abkowicza zostały przeznaczone na kaplicę. Mimo stale zmniejszającej się liczby wiernych działała ona aż do roku 1989. Hazzan Abkowicz odwiedzał także społeczności karaimskie w innych ośrodkach, udając się tam czy to w celu odprawienia nabożeństw z okazji świąt, czy to z ostatnią posługa dla zmarłych członków społeczności. Prowadził szeroką korespondencję z wiernymi w Polsce i na Litwie, na ich prośby odprawiał w domowej kaplicy modły błogosławiące (ałhysz) i za dusze zmarłych (sahyncz). Funkcje kapłańskie pełnił do śmierci w 1992 r.

Społeczne życie Karaimów weszło w nową fazę w roku 1997 z chwilą rejestracji we Wrocławiu Związku Karaimów Polskich w RP, organizacji, która zrzesza przedstawicieli karaimskiej mniejszości etnicznej zamieszkałych w Polsce oraz członków ich rodzin. Główne kierunki działalności ZKP to: szerzenie wiedzy na temat mniejszości karaimskiej wśród społeczeństwa polskiego oraz podtrzymywanie poczucia tożsamości narodowej społeczności karaimskiej. Pierwszym poważnym wyzwaniem organizacyjnym Związku stały się Karaj Kiuńlari Dni Karaimskie, które odbyły się w dniach 19-21 września 2003 roku w Warszawie. Uczestnikami Dni Karaimskich było 279 gości, w tym 95 z Polski, pozostali z 11 krajów: Litwy (82), Krymu i Ukrainy (37), Rosji (32), Francji (3), Australii (1), Estonii (3), Kanady (1), Niemiec (3), Węgier (10, USA (2). Na program imprezy złożyły się: seminarium pt. „Dziedzictwo narodu karaimskiego we współczesnej Europie”, koncert twórców kultury karaimskiej, warsztaty kuli- 
narne, taneczne oraz prezentacje kuchni karaimskiej. Schemat tego spotkania był w kolejnych latach powielany na szeregu spotkań popularyzatorskich i konferencjach naukowych organizowanych lub współorganizowanych przez Związek, a odbywających się w Warszawie, Trójmieście, Przemyślu, Poznaniu, Krakowie, Toruniu i innych miejscowościach.

W roku 2003 we współpracy ze Stowarzyszeniem Kulturalnym Karaimów Litwy powołano taneczno-wokalny zespół dziecięcy pod nazwą „Sanduhacz”. Członkami zespołu były dzieci karaimskie z Polski i Litwy. We wrześniu 2007 roku członkowie polskiej sekcji podjęli decyzję o zmianie nazwy zespołu na Karaimski Zespół Folklorystyczny „Dostłar” i kontynuacji współpracy z sekcją litewską występująca pod nazwą „Sanduhač” podczas kolejnych edycji warsztatów kultury karaimskiej i letnich szkół języka karaimskiego. Zespół z dużym powodzeniem występuje w Polsce i za granicą - na Litwie i na Ukrainie.

Utworzono i na bieżąco aktualizowano serwis internetowy www.karaimi.org, obejmujący w chwili obecnej również wersję elektroniczną czasopisma „Awazymyz”, które po kilkuletniej przerwie (pierwszy numer ukazał się w 1989 r.) zaczęło ukazywać się we Wrocławiu w roku 1999 w wersji elektronicznej, a w wersji drukowanej w 2004. W 2004 roku rozpoczęła działalność wydawniczą „Bitik” - oficyna wydawnicza ZKP. Pierwszym efektem jej działania była książka Karaj Kiuńlari pod red. M. Abkowicz i H. Jankowskiego, która ujrzała światło dzienne w grudniu 2004 r. W roku 2005 wydano pracę S. Szyszmana pt. Karaimizm. Historia i doktryna, zaś w roku 2006 Zarys religii karaimskiej A. Zajączkowskiego. W roku 2007 rozpoczęto prace nad e-jazyszłar Karaimskq Bazq Literacko-Bibliograficzna, dostępną na stronach www.jazyszlar.karaimi.org.

W latach 2006-2007 przeprowadzono prace remontowo-budowlane i konserwatorskie na terenie Karaimskiego Cmentarza w Warszawie podczas, których wybudowano aleję cmentarną, uporządkowano teren cmentarza, odnowiono ogrodzenie oraz poddano konserwacji najstarsze pomniki pochodzące jeszcze z XIX wieku.

Podsumowując ponad sześćdziesiąt lat obecności społeczności karaimskiej na terenach Dolnego Śląska można powiedzieć, że ta niewielka i stale zmniejszająca się grupa osób potrafiła znaleźć swoje miejsce $\mathrm{w}$ wielokulturowym Wrocławiu, tworząc własne struktury organizacyjne i prowadząc działalność popularyzatorską oraz kulturotwórczą w różnych dziedzinach, obejmując swym zasięgiem teren całej Polski i podtrzymując stały kontakt ze środowiskami karaimskimi na całym świecie. Obecnie pomimo niewielkiej liczby osób pochodzenia karaimskiego Wrocław w dalszym ciągu stanowi ważne miejsce na karaimskiej mapie Europy. 